\title{
Recent variations of Ghiacciaio del Calderone, Abruzzi, Italy
}

\author{
A. F. Gellatly, \\ Department of Geography, University of Birmingham, Birmingham B15 2TT, England \\ C. SMiraglia, \\ Dipartimento di Scienze della Terra, Universita degli Studi, 20133 Milano, Italy \\ J. M. GRove, \\ Girton College, Cambridge CB2 OfG, England \\ R. LATHAM \\ Department of Land Surveying, University of East London, Dagenham, Essex RM8 2AS, England
}

\begin{abstract}
Results of a detailed topographic survey of Ghiacciaio del Calderone, Italy, the southernmost in Europe, are described and compared with those of surveys made in earlier years. Recession and thinning, much affected by micro-climate, have been the predominant state of health during the 20th century. Between 1916 and 1990, volume is estimated to have been reduced by about $90 \%$ and area by about $68 \%$.
\end{abstract}

\section{INTRODUCTION}

Ghiacciaio del Calderone $\left(42^{\circ} 28^{\prime} 15^{\prime \prime} \mathrm{N}, 12^{\circ} 27^{\prime} 08^{\prime \prime} \mathrm{E}\right)$ is of particular interest as the southernmost glacier in Europe. It is situated in a north-northeast-facing cirque cut into the limestones of Corno Grande $(2912 \mathrm{~m})$, the highest peak of Gran Sasso, Abruzzo, Italy (Fig. 1). Not much is known about its history. The earliest map on which it appears dates from 1887 but its representation is only vague. Observations and occasional surveys have been made since 1893 (Bonarelli, 1893). The history of Ghiacciaio del Calderone has been documented by Smiraglia (1990) and Smiraglia and Veggetti (1991), and preliminary geoelectrical surveys of ice volume have been conducted by Smiraglia and Veggetti (1992). A detailed topographic and geomorphological survey was carried out during the period from 30 August to 3 September 1990. Comparison of the state of the glacier in 1990, with available information from earlier years, suggests that Ghiacciaio del Calderone may disappear within 50 years, should current rates of wastage continue.

Ghiacciaio del Calderone now clings to the steep slope of the headwall, a thin lobe of ice still stretching across the cirque floor. The ice extends from a maximum altitude of $2839 \mathrm{~m}$ to a minimum of $2670 \mathrm{~m}$. Below $2760 \mathrm{~m}$, the surface is effectively buried by a layer of debris up to $1 \mathrm{~m}$ thick. The glacier is confined within the cirque behind a prominent bedrock ridge at the lip. The terminal moraine lies on the lip at $2700 \mathrm{~m}$.

Prominent ice-cored moraines and ice-deformed talus slopes occupy the slopes above the tongue. Two clearly

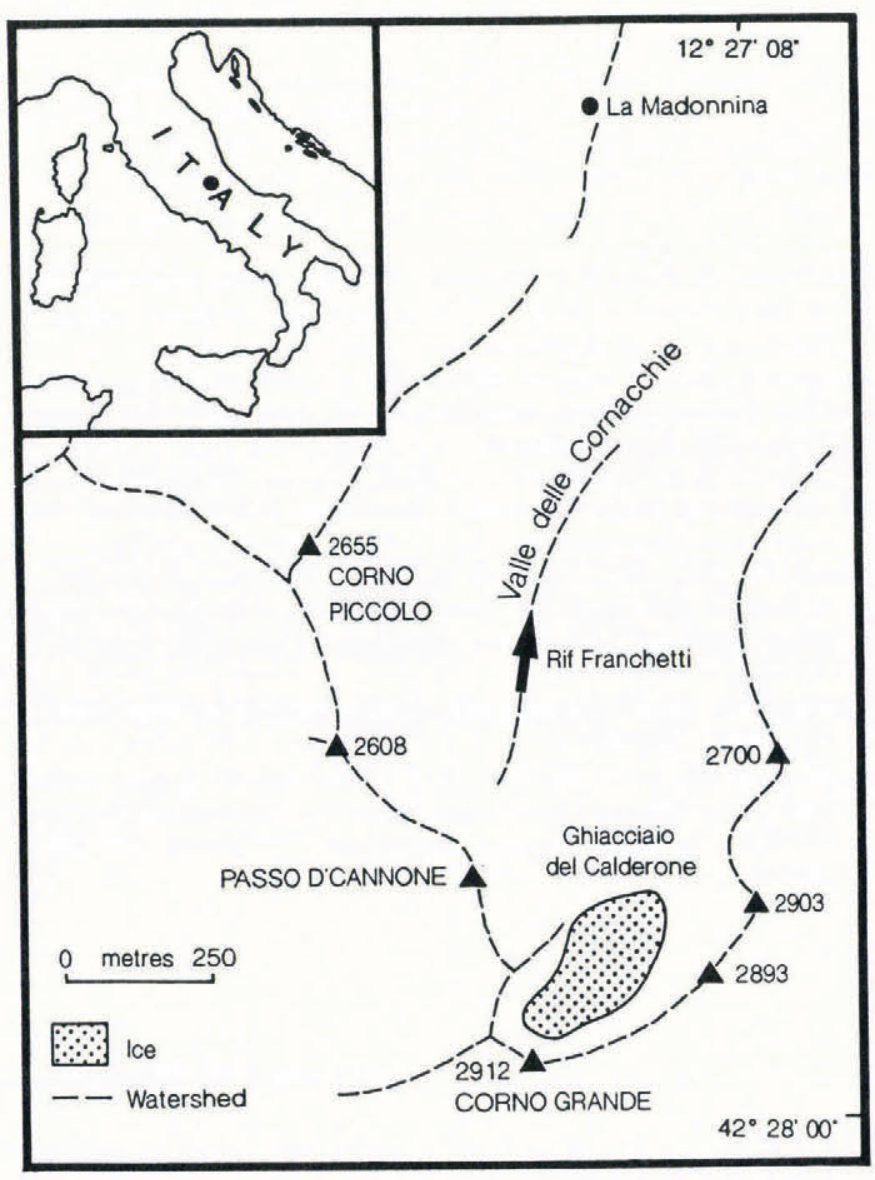

Fig. 1. Ghiacciaio del Calderone, Gran Sasso d'Abruzzi, Italy. 
defined trim lines, highlighted by sharp contrasts in weathering, cut across the side and headwalls of the cirque. The upper trim line rises from a height of about $2750 \mathrm{~m}$ on the side walls above the snout to over $2880 \mathrm{~m}$ along the headwall. This may well pre-date the historical records. The fresher and lower line rises from $2720 \mathrm{~m}$ at the lip of the cirque to merge with the upper trim line on the headwall below Corno Grande (2912 m). During a survey of the glacier in 1966 by Tonini, a marker was placed close to the ice edge at an altitude of $2730.4 \mathrm{~m}$ which coincides with the position of the lower trim line. Earlier photographs show that ice depletion had begun shortly after 1934, when the glacier extended up to this level. Ice depletion had been most extensive in the lower ablation basin, which was over $30 \mathrm{~m}$ below the lower, historical trim line by 1966 . In 1990, ice buried by rock debris lay $18.4 \mathrm{~m}$ below the survey marker. The upper glacier surface is consistently $15-20 \mathrm{~m}$ below the lower trim line compared with $30-40 \mathrm{~m}$ near the glacier snout.

A weakly developed ridge of clastic material runs obliquely across Valle delle Cornacchie above Refugio
Franchetti and descends to an altitude of about $2500 \mathrm{~m}$. This is the only geomorphological indication of ice expansion outside the cirque and is the likely extension of ice during the Little Ice Age.

\section{HISTORICAL GLACIER SURVEYS}

A sketch survey of Ghiacciaio del Calderone made by Marinelli and Ricci (1916) showed the approximate extent of the ice at that time (Fig. 2a) but was not very accurate. A more accurate survey was completed by Sforzizi and Tonini in 1934 (1934-37; Fig. 2b). Comparison of the early maps suggests a reduction in area of about $14-15 \%$ between 1916 and 1934 but it provides only a rough guide to the extent of change because of their lack of precision and the difficulty of identifying the ice edge beneath the debris cover. The specific figures given for the length of Ghiacciaio del Calderone do not clarify the situation, since these suggest that the glacier was $40-50 \mathrm{~m}$ longer in 1934 than in 1916 .

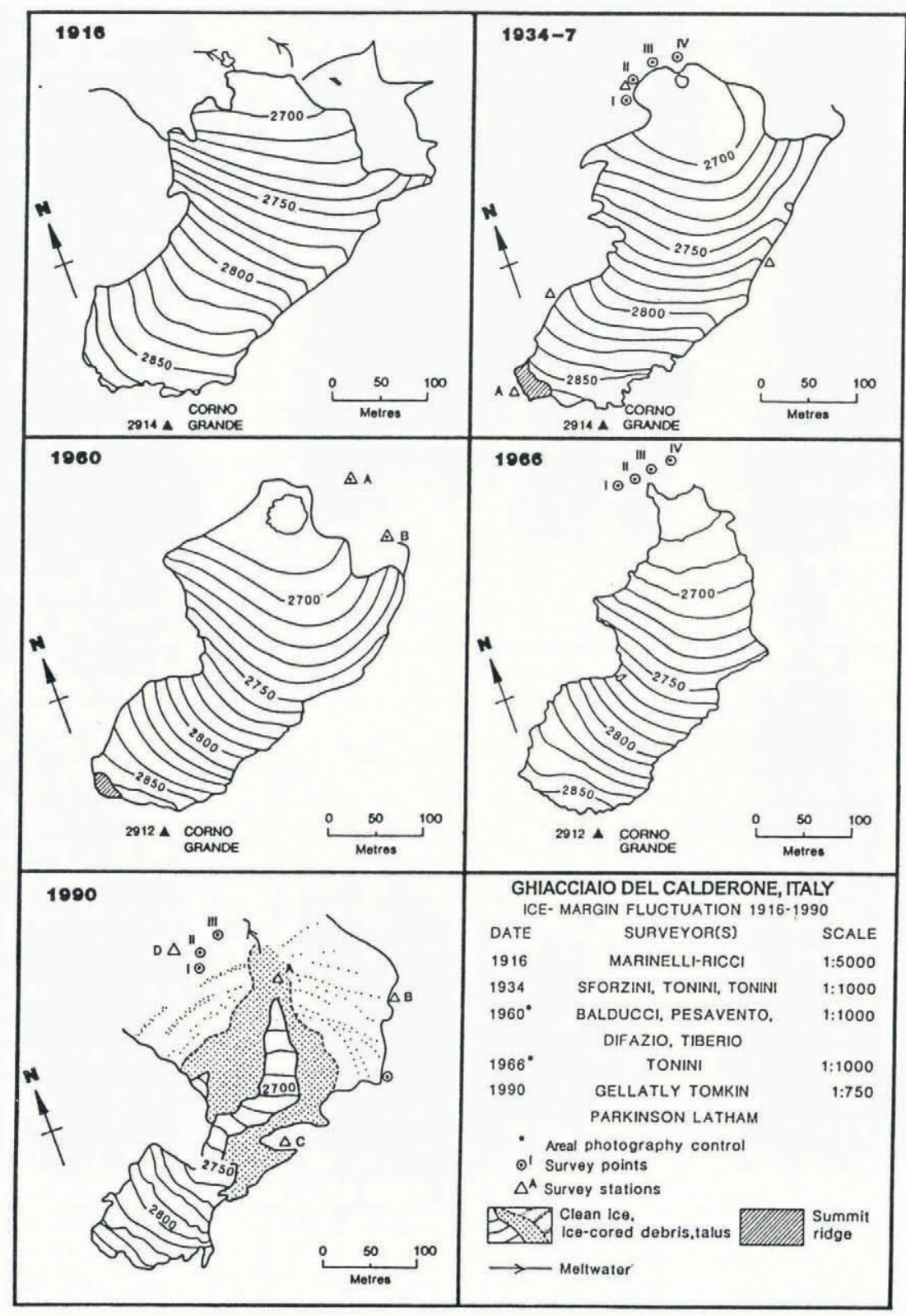

Fig. 2. Surveys of Ghiacciaio del Calderone, 1916-90. 
Systematic observations were begun by Tonini (1934, $1936,1955,1963)$. Detailed topographic surveys were undertaken in 1934-37, 1958-60 (Fig. 2c) and 1966 (Fig. 2d). Tonini calculated that between 1934 and 1960 the glacier had thinned overall by an average of $7 \mathrm{~m}$ but in the lower section by nearly $20 \mathrm{~m}$. He put the loss in volume between 1934 and 1960 at about $4.2 \times 10^{5} \mathrm{~m}^{3}$. Wastage has since continued. A reduction in surface area of about $68 \%$ and of ice volume, possibly by as much as $90 \%$, occurred between the surveys of 1934 and 1990 (Fig. 2e; Table 1). Loss was most pronounced between 1960 and 1990, the area of clean ice decreasing by approximately $20 \%$ (Smiraglia and Veggetti, 1992), whilst the depletion of debris-covered ice in the cirque amounts to over $60 \%$. Estimation of volumetric change is handicapped by the existence of a substantial amount of buried ice, the full extent of which is not accurately known.

Table 1. Changes in the area of Ghiacciaio del Calderone, 1916-90

Date
ha

$\begin{array}{llll}1916 & 7.0^{*} & & \\ 1934 & 6.0 & -14.3 & ?(1916-34) \\ 1960 & 6.0^{\dagger} & 0^{\dagger} & (1934-60) \\ 1966 & 4.5 & -25 & (1960-66) \\ 1990 & 2.0^{\ddagger} & -55.6 & (1966-90)\end{array}$

\footnotetext{
* Based on field sketches.

${ }^{\dagger}$ Derived from aerial photography. May include lying snow.

$\ddagger$ Derived from topographic survey.
}

The course of ice-front recession is difficult to determine. At its fullest extent, during the Little Ice Age, the glacier filled the cirque basin and built up against the proximal front of the moraine, whilst a small ice lobe spilled over into Valle delle Cornacchie. The front is now withdrawn into a hollow behind the moraine. Tonini (1963) recorded frontal advances of $+5.5 \mathrm{~m}$ in 1936 and $+7.2 \mathrm{~m}$ in 1938 . By 1966 , the ice had retreated $15-20 \mathrm{~m}$ from the position shown on the 1934 map, while comparison of the 1966 and 1990 maps indicates a further recession of $60-70 \mathrm{~m}$.

Some of the survey markers on the terminal lobe established by Sforzini and others (Tonini, 1963) were recorded during the 1990 survey. But, the recorded heights of the same markers in the various publications differ. This is attributed to melting of ice within the moraine. In 1934, Point l (Fig. 2b) was given a height of $2693.7 \mathrm{~m}$, but in 1990 it was found to be at $2678.7 \mathrm{~m}$. Point III was recorded at $2690.7 \mathrm{~m}$ in 1934 and $2683.9 \mathrm{~m}$ in 1990. Similar discrepancies have been found with the heights of points II and IV.

A geoelectrical survey of the ice lobe on the cirque floor revealed a depth of $10 \mathrm{~m}$ (Smiraglia and Veggetti, 1992). Further measurements of depths up to $16 \mathrm{~m}$ were made on exposed ice faces, whilst measurements in the crevasses indicate that in some places the ice is no more than 3-8 $\mathrm{m}$ thick. The depth of the upper Ghiacciaio del Calderone is unknown but may be quite thin. Inspection of the ice from the Corno Grande ridge above suggested that it was little more than $5 \mathrm{~m}$ thick. Substantial quantities of buried ice underlie both the frontal moraine and rockfall-covered slopes of the lower basin. Currently, this is estimated to include roughly $40 \%$ of the volume, indicating that approximately $120000 \mathrm{~m}^{3}$ of ice remain in the Ghiacciaio del Calderone cirque.

\section{DISCUSSION}

It is clear that recession has not taken place at a uniform rate. In addition to the small advances measured by Tonini (1963), Zanon (1963-64) noted a period of positive mass balance in the early 1960 s and observed ice advances during 1962-63 at several survey stations. The glacier was recorded as either stationary or advancing in 24 of the 35 years during the period 1925-60. A small advance of ice occurred in 1969; it was then stationary in the early 1970s but withdrew sharply in 1974. In 1979, the tendency was again towards increase. Although Ghiacciaio del Calderone did not show so much tendency to expand during the period $1960-80$ as many of the other Alpine glaciers, there was a slight overall increase in volume (Pelfini and Smiraglia, 1988).

Tonini (1963) and Smiraglia and Veggetti (1991) attempted to investigate in a general way the relations between glacier behaviour and meteorological variables, making use of data from Isola del Gran Sasso, the nearest station, $8 \mathrm{~km}$ from the glacier at an elevation of $420 \mathrm{~m}$ (Fig. 3). Three periods with high precipitation and lowered temperature occurred: the second half of the 1930 s, the later 1950 s to the early 1960 s and during the second half of the 1970s. The coldest period was the last; in 1973-78 the 5 year running mean annual temperature was below the $12.2^{\circ} \mathrm{C}$ norm of the period $1925-89$. In 1976 , the 5 year running mean temperature was lowest at $10.1^{\circ} \mathrm{C}$ and in the same year the highest total annual precipitation was recorded at $1779 \mathrm{~mm}$ (cf. average annual precipitation $1919-89$ of $1185 \mathrm{~mm}$ ). During these periods, the ice was almost always covered by old snow and firn at the end of the ablation season, indicating positive mass balances.

From the mid 1940s to the early 1950 s, in the second half of the 1950s and in the 1980s, conditions were unfavourable for glacier growth. From 1966 to 1972, mean annual temperature was constantly above normal, with a maximum for the whole series of $14.5^{\circ} \mathrm{C}$ occurring in 1967. Precipitation was almost always below normal from 1981 to 1989. Unfortunately, Ghiacciaio del Calderone was not observed every year, especially after the mid 1960s but, when it was monitored, it was almost always without an old snow cover.

Ghiacciaio del Calderone is greatly influenced by local climate. Its survival during the 20th century, whilst the theoretical snow-line altitude has been above the highest peaks of Gran Sasso (Tonini, 1963), is to be attributed to 

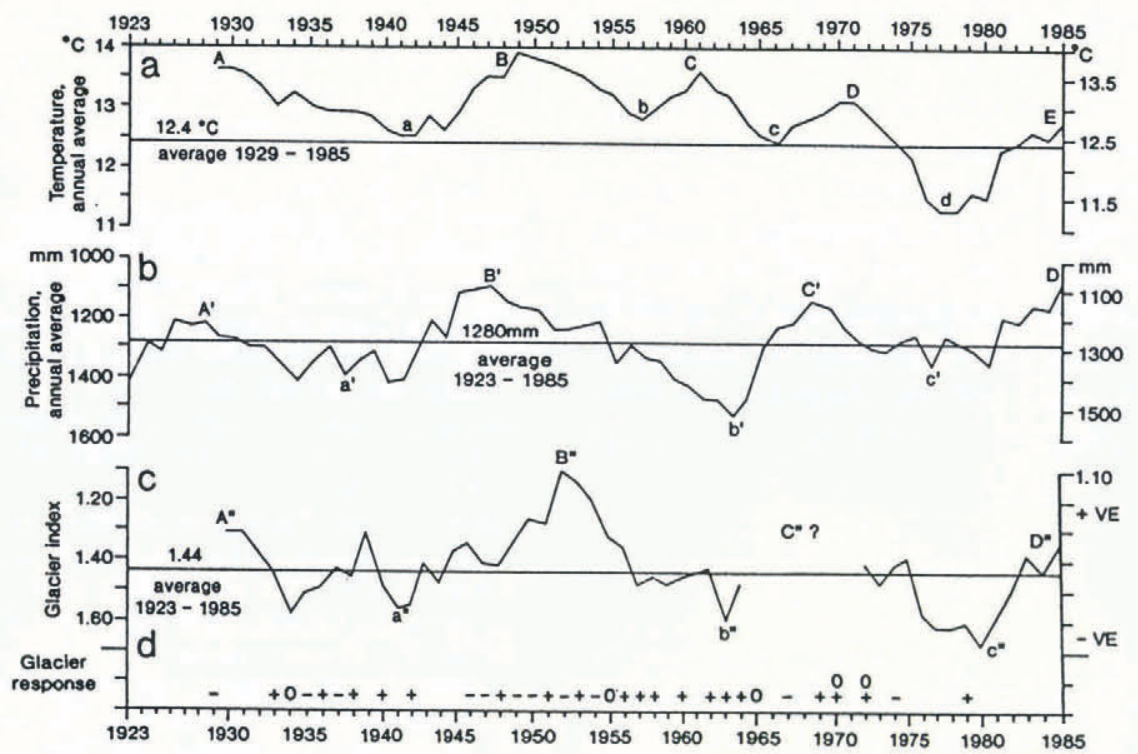

\begin{abstract}
Fig. 3. Climate and glacier variations showing the principal periods of glacier growth (Isola del Gran Sasso and Ghiacciaio del Calderone): a. Mean annual temperature (smoothed 5year averages), 1929-85; b. Mean annual precipitation (smoothed 5year averages), 1923-85; c. Glacier index (+ve advance, -ve retreat), 1929-30 to 1984-85; d. Glacier response based on direct field observations. (From Smiraglia and Veggetti, 1991.)
\end{abstract}

topoclimatic factors such as northerly aspect, shading by precipitous cirque walls, extensive debris cover and additional snow accumulation by wind and avalanches. However, the periods during which the climate favoured positive mass balances saw only slight increases of volume, which were insufficient to interrupt the general recessional trend to the same extent as with valley glaciers in the central Italian Alps. For instance, while Ghiacciaio del Forni, in Valtellina, had withdrawn $1100 \mathrm{~m}$ in 192571, it advanced about $300 \mathrm{~m}$ between 1972 and 1981, before resuming recession. The behaviour of other cirque glaciers in Italy, including Ghiacciaio del Sforzellina, has been more complex and less linear than that of valley glaciers (Belloni and others, 1985; Zanon, 1985).

It is evident, from the historical surveys of Ghiacciaio del Calderone, and from recent detailed observations, that its continued survival is a function not only of climate but also the effectiveness of topographical protection. The sensitivity to local climate is reflected in the rapid response to adjustment to changes in mass balance during the last century and in particular since the period of observations by Tonini in the 1960s. Ghiacciaio del Calderone has been responding to a negative mass balance throughout the latter part of the 20 th century and, as such, the time-scale for adjustment can theoretically be assessed using measurements of ice depletion (volume loss) and glacier shortening (Jóhannesson and others, 1989). However, despite repeated historical surveys of Ghiacciaio del Calderone, concern is expressed regarding their accuracy for reconstructing the former extent and thickness of ice in the Ghiacciaio del Calderone basin. Furthermore, topographic irregularities, such as the elevated lip of the basin, restrict glacier elongation at rates commensurate with noticeable ice thickening. The models proposed by Jóhannesson and others (1989) assumed distinctive glacier-terminus characteristics, knowledge of steadystate conditions and similarity of long-profile geometry.
These assumptions cannot be met satisfactorily under the present conditions of glacier decay. The extreme negative net-balance conditions of Ghiacciaio del Calderone dominate the current behaviour pattern and the most recent, detailed topographic survey will form a base line for accurate assessments of the volume flux.

\section{GONGLUSIONS}

Recession has dominated the 20th century history of Ghiacciaio del Calderone. The very rapid rate of loss of area and volume which seems to have occurred since 1960 is typical of glacial history not only in Europe but also elsewhere in the world (Grove, 1988). Wastage has been interrupted by stationary periods or small advances. Available information does not suggest very close parallelism with the timing of fluctuations farther north in Europe.

Apparent increase in area between 1916 and 1934 could be due to advances immediately after 1916, roughly concurrent with those in the Alps (Grove, 1988; Patzelt, 1990), but could also be accounted for by the inaccuracy of the 1916 sketch map. The timing of the more recent small advances can be compared with other European glaciers. While some of the glaciers of Mont Blanc showed minor increases in extent between about 1930 and 1935, much more pronounced were the retreats after about 1945 and advances in the 1960s and 1970s which were not observed on Ghiacciaio del Calderone. The details of the Ghiacciaio del Calderone variations are heavily dependent on local conditions within the cirque. Variations of wind direction and extent of eddying are suspected to have an important influence on accumulation and shading on ablation. It is such factors, together with the frequency of rockfalls, which account for the present survival of Ghiacciaio del Calderone, despite its southerly position. 


\section{ACKNOWLEDGEMENTS}

The 1990 field survey was carried out as part of EC contract EV4C-0044-UK (H). Considerable assistance was given by J. Tomkins, Department of Land Surveying, University of East London, and R. Parkinson, University of Plymouth. The manager and staff of Refugio Franchetti offered generous hospitality. Mr K. Burkhill, cartographer, Department of Geography, University of Birmingham, kindly prepared the diagrams. Further details of the 1990 survey are available from A.F.G. and R.L.

\section{REFERENCES}

Belloni, S., G. Catasta and C. Smiraglia. 1985. Parametri climatici e variazioni glaciali nel periodo 1950-1982. Geogr. Fis. Din. Quat., 8(2), 97-123.

Belloni, S., G. Catasta and C. Smiraglia. 1987. Un sessantennio di variazioni dei ghiacciai italiani. Bolletino del Comitato Alpino Italiano 68, 65-75.

Bonarelli, G. 1893. Osservazioni sul Toarciano e sull'Aaleniano dell'Appennino centrale. Boll. Soc. Geol. Ital. 12, 195-254.

Grove, J. M. 1988. The Little Ice Age. London and New York, Methuen.

Jóhannesson, T., C. Raymond and E. Waddington. 1989. Time-scale for adjustment of glaciers to changes in mass balance. $\mathcal{H}$. Glaciol., 35(121), 355-369.

Marinelli, O. and L. Ricci. 1916. Alcune osservazioni sul ghiacciai del Gran Sasso. Riv. Geogr. Ital., 23, 399-405.
Patzelt, G. 1990. Schnee, Eis und Waser der Alpen in einer warmeren Atmosphäre. Eidg. Tech. Hochschule, Zürich. Versuchsanst. Wasserbau, Hydrol. Glaziol. Mitt. 108, 49-60.

Pelfini, M. and C. Smiraglia. 1988. L'evoluzione recente del glacialismo sulle Alpi Italiane: strumenti e temi di ricerca. Boll. Soc. Geogr. Ital., 11(5), 127-154.

Ricci, L. 1917. Sul ghiacciaio del Gran Sasso. Riv. Geogr. Ital., 24, 68-69. Smiraglia, C. 1990. Il ghiacciaio del Calderone nel Gran Sasso d'Italia. Recenti ricerche. Bolletino del Club Alpino Italiano, L'Aquila, 49-53.

Smiraglia, C. and O. Veggetti. 1991. Il ghiacciaio del Calderone al Gran Sasso d'Italia. Varizioni recenti e relazioni con il clima. Mem. Soc. Geogr. Ital., 46, 183-198.

Smiraglia, C. and O. Veggetti. 1992. Recenti osservazioni sul ghiacciaio del Calderone (Gran Sasso d'Italia, Abruzzo). Boll. Soc. Geogr. Ital. 9(4), 269-302.

Tonini, D. 1934. Appunti sul ghiacciaio del Calderone del Gran Sasso d'Italia. Bolletino del Comitato Glaciologico Italiano, 14, 185-194.

Tonini, D. 1936. Il ghiacciaio del Calderone del Gran Sasso d'Italia. Bolletino del Comitato Alpino Italiano 43, 188-201.

Tonini, D. 1955. Le glacier du Calderone du Gran Sasso d'Italia. International Association of Scientific Hydrology Publication 39 (General Assembly of Rome - Snow and Ice), 429-441.

Tonini, D. 1963. Il ghiacciaio del Calderone del Gran Sasso d'Italia. Bolletino del Comitato Glaciologico Italiano, II Serie, 10, 1961, 71-134.

Zanon, G. 1963-64. Ghiacciaio del Calderone-relazioni delle campagne glaciologiche. Bolletino del Comitato Glaciologico Italiano, II Serie, 13(1), 139-143.

Zanon, G. 1985. L'attuale tendenza evolutiva dei ghiacciai delle Alpi Italiane. Geogr. Fis. Din. Quat., 8(2), 89-96

The accuracy of references in the text and in this list is the responsibility of the authors, to whom queries should be addressed. 